Original Contribution

\title{
ANALYSIS OF SIZE-AGE, SEXUAL STRUCTURE AND CONDITION OF POPULATIONS OF CARASSIUS GIBELIO (PISCES: CYPRINIDAE) FROM TWO WATER BASINS IN GALABOVO REGION (SOUTHERN BULGARIA)
}

\author{
Z. Zhelev ${ }^{1 *}$, P. Boyadzhiev ${ }^{2}$, M. Angelov ${ }^{3}$ \\ ${ }^{1}$ Department of Human Anatomy and Physiology, Faculty of Biology, University of Plovdiv "Paisii \\ Hilendarski”, Plovdiv, Bulgaria \\ ${ }^{2}$ Department of Zoology, Faculty of Biology, University of Plovdiv "Paisii Hilendarski”, Plovdiv, \\ Bulgaria \\ ${ }^{3}$ Basin Directorate - Plovdiv, Plovdiv, Bulgaria
}

\begin{abstract}
The present work was aimed at determining the population structure of silver Prussian carp (Carassius gibelio) populations that inhabit two anthropogenically polluted water basins from the region of the town of Galabovo (Southern Bulgaria) - the river Sazliyka (Population A) and the Rozov Kladenets reservoir (Population B). Total of 558 specimens from the river Sazliyka and 1004 specimens from the Rozov Kladenets reservoir were caught with fishing nets (cast or throw net) every month during April-October 2011. The sex composition of the C. gibelio population from the river Sazliyka was $99.64 \%$ females and $0.36 \%$ males; and the maximum age group III. In the population from the Rozov Kladenets reservoir, the sex composition was $99.30 \%$ females and $0.70 \%$ males; the maximum age group - VI. Standard length and total weight of the specimens from Population A ranged from 8.7 to $22.6 \mathrm{~cm}$ and 22.7 to $163.5 \mathrm{~g}$. Standard length and total weight of the specimens from Population B ranged from 9.8 to $26.6 \mathrm{~cm}$ and 28.5 to $318.3 \mathrm{~g}$. CF values in female individuals from all age groups of $C$. gibelio population from the river Sazliyka were statistically significantly lower than these in female individuals from the respective age groups in the population from the Rozov Kladenets reservoir.
\end{abstract}

Key words: Prussian carp, sex ratio, age differentiation, condition factor, the river Sazliyka, the Rozov Kladenets reservoir, anthropogenic pollution

\section{INTRODUCTION}

According to Holopainen et al. (1), Carassius spp. is a species that lives in warm waters and belongs to the group of Boreal fish. Thus, it has a wide geographic distribution especially in Eastern Europe and its distributional area is continuously increasing (2-5). In recent years, a growing belief appeared in ichthyology, however controversial, that silver Prussian carp Carassius gibelio (Bloch, 1882) and crucian carp Carassius carassius (Linnaeus, 1758) have the status of separate species (6-10), although they belong to Carassius auratus complex which is widespread in Europe and Asia.

*Correspondence to: Zhivko M. Zhelev, University of Plovdiv "Paisii Hilendarski", Faculty of Biology, Department of Human Anatomy and Physiology, 24 Tsar Assen Str., 4000 Plovdiv, Bulgaria; e-mail: zhivko-m@uni-plovdiv.bg
In many water bodies in Europe, at the end of the last and the beginning of this century, in conditions of competitive habitation, in an unfavorable environment and deteriorating food base, $C$. gibelio have gradually displaced from the ecological niches such local autochthonous species from the family Cyprinidae as Cyprinus carpio Linnaeus, 1758 and Tinca tinca (Linnaeus, 1758) (11-13), as well as $C$. carassius $(3,14)$. The Prussian carp and the crucian carp are resistant to anthropogenic pollution and they can inhabit an environment with low oxygen content, at low $\mathrm{pH}$ values. When living in pollution, $C$. carassius degenerate, as their bodies become lower, their heads become bigger and they grow slowly $-C$. carassius morpha humilis (10). C. gibelio grows faster and matures sexually earlier than $C$. carassius. $C$. gibelio can form unisexual populations, only females that 
can reproduce by a specific parthenogenesis: gynogenesis (15).

Literature data have proved that sizes and the maturation age of $C$. gibelio vary a lot, in dependence on the oxygen regime and food base status. It was found that $C$. gibelio sexually mature at the age of 3-4 years and they reach a length of 7-8 $\mathrm{cm}$ in shallow and freezable water basins, while in favorable environmental conditions (non-freezing waters and a rich nutrient base) the sexual maturation occurs 1-2 years earlier, at a body length of $10 \mathrm{~cm}$ (16). Furthermore, the growth of $C$. gibelio can considerably vary in the same water body in changing environmental conditions (17).

Currently, $C$. gibelio is the most common species in the Rozov Kladenets reservoir, however, fishermen only catch it as a sport and it is economically irrelevant. Perhaps, the abundance of $C$. gibelio may have caused a reduction of fish populations, which used to be common to the basin, from the family Cyprinidae: C. carpio; Leuciscus cephalus (Linnaeus, 1758); Rutilus rutilus (Linnaeus, 1758); and even to be the reason for the absence of $C$. carassius and Abramis brama (Linnaeus, 1758). In this aspect, it is a matter of great interest to study the status of $C$. gibelio populations that are the most common species in the ichthyofauna of the two water basins. There isn't any information for bio-ecological studies done with $C$. gibelio populations from the river Sazliyka and the Rozov Kladenets reservoir; and this motivates the conduct of the present study.

\section{Purpose and objectives}

The purpose of this study was to investigate the age-sex structure of the populations C. gibelio, living in two anthropogenically polluted water basins near the town of Galabovo: the river Sazliyka and the Rozov Kladenets reservoir, as well as to assess the water condition basing on the analysis of the main morphometric parameters (standard length - SL, total weight TW and condition factor - CF)

\section{MATERIAL AND METHODS}

\section{The investigation area}

The region near the town of Galabovo $\left(42^{\circ} 07^{\prime} \mathrm{N}\right.$, $25^{\circ} 51^{\prime} \mathrm{E}, 93 \mathrm{~m}$ altitude) is a center of the mining and energy industry. The power plants "Brickell" EAD and AES "Galabovo" are to the east, 4-5 $\mathrm{km}$ away from the town; and TPP - "Contour global Maritsa East - 3" is situated 10-12 km away from the town, to the southeast. The power plants operate with the lignite coal mined there, causing the town and the entire municipality to be designated as one of the most dust and sulfur dioxide polluted areas in the country and globally as well. The amount of sulfur dioxide released into the air ranges from 25 to 45 times the permissible limits. The dust content is $1-2$ to 8 times higher than the permissible limits, and emissions of fly ash are on average twice the standards (18). Due to discharge (release) of untreated sewage and industrial water and lack of necessary water treatment facilities in the area, the water in the river Sazliyka and the Rozov Kladenets reservoir has periodically been deteriorated, according to the indicators and standards for categorization of surface waters in the Republic of Bulgaria. Their water regularly does not meet the standards of the project II-III categories.

The investigations were conducted in the two water basins located in the region of the town of Galabovo: the river Sazliyka and the Rozov Kladenets reservoir. In the river Sazliyka, catches were performed north of the town, near the sluice gates, where water is diverted to TPP "Brikell" and AES "Galabovo" - Site A. In the Rozov Kladenets reservoir, fish was caught on the eastern shore, at the confluence of the river Sokolitsa - Site B (Figure 1).

The river Sazliyka originates (651 in altitude) from the Sredna Gora range to the north of the village of Kazanka under the name Toplitsite (Varbitsa), after that it reaches the Stara Zagora mineral baths, where it is known as the river Banyanska, passes through the village of Rakitnitsa (as Syutliyka or Rakitnitsa) and after the confluence of the river Bedechka, south of the town of Stara Zagora, it flows south in a broad alluvial valley under the name Sazliyka. Its two largest left tributaries, the rivers Blatnitsa (54 km long) and Sokolitsa $(60.5 \mathrm{~km})$, flow into it near the town of Radnevo and to the south of the town of Galabovo, respectively. One of the big left tributaries, the river Ovcharitsa (71.5 $\mathrm{km}$ ), has had its bed changed since the 1990s by the coal mining concessionaire "Maritsa East Mines" EAD in the town of Radnevo. The tributary flows into the river at its old mouth, to the south of the village of Lyubenovo, where its flow is greatly reduced and often completely stopped. The total length of the river upto where it joins the river Maritza (78 $\mathrm{m}$ in altitude), south of the town of Simeonovgrad, is $145.4 \mathrm{~km}$ with a catchment area of $3300 \mathrm{~km}^{2}\left(16^{\text {th }}\right.$ longest in Bulgaria). The average flow of the river at the town of Galabovo is $18.0 \mathrm{~m}^{3} / \mathrm{s}$. 


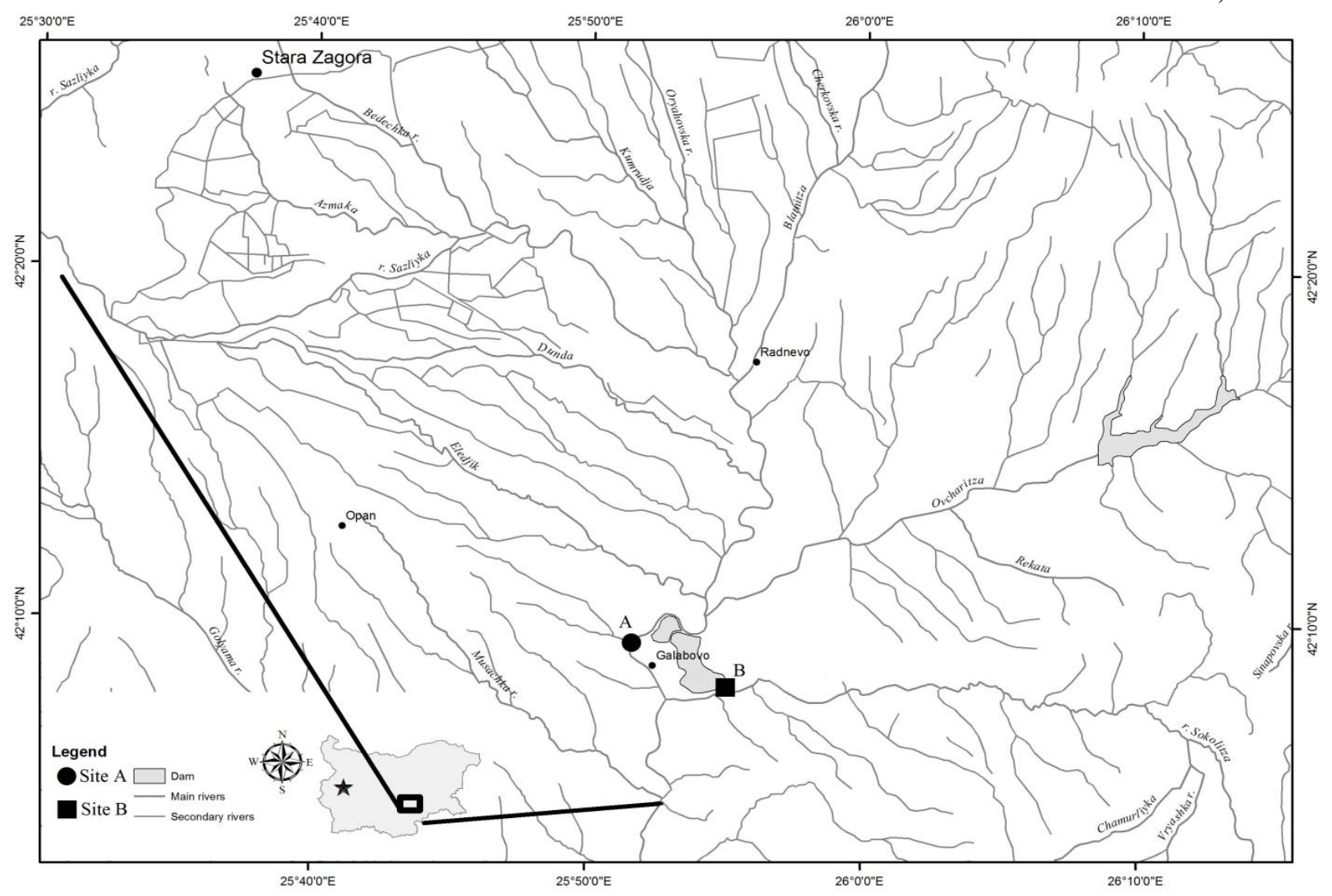

Figure 1. Map of the investigated region: Site A - the river Sazliyka; Site B - the Rozov Kladenets reservoir

The Rozov Kladenets reservoir was built for the purposes of the neighboring TPP "Brikell" and AES "Galabovo", where lignite coal is burnt; industrial effluents that are used to cool the turbines enter the dam; it is in direct connection with the rivers Sazliyka and Sokolitsa.

The entire ecosystem of the river Sazliyka (from the source to the mouth) is classed by order RD970/28.07.2000 as an environmentally sensitive area under Directive 91/271/EEC (19). It is also included in the protected areas by the National Ecological Network "NATURA" 2000 (code: BG0000425) under Directive 92/43/EEC (20) on the conservation of natural habitats and wild fauna and flora. In 1997, the Rozov Kladenets reservoir and some lands on its shores were declared an Important Bird Area (in the list of Bird Life International). It is located in the town of Galabovo region and it is connected with the river Sazliyka. In 1998, the dam was declared a "CORINE" biotope because of its European importance for the preservation of rare and endangered bird species. In 2008, it was declared a protected area by "NATURA" 2000, code BG0002022.
Data from physicochemical analysis of the water ecosystems studied

Monitoring and control of the river Sazliyka surface water was performed by the National System for Environmental Monitoring (NSEM). Based on data from the annual report on the environmental status (waters) for the period 2001-2012 from the Executive Environmental Agency (http://eea.goverment.bg) and the data on the physicochemical analysis of the river Sazliyka water for 2001-2012 in the newsletters of Basin Directorate of Water Management in the East Aegean Sea - Plovdiv (http://www.bgibr.org), the river is considered one of the most polluted in Bulgaria (21). The contamination exceeds the permissible values for Bulgaria Water Category I (clean), and also the expected values - Water Category II (slightly polluted) and Water Category III (moderately polluted) under Regulation № 7 of 08.08.1986 (22) on indicators and standards for running waters in Bulgaria. The main pollutants are nitrite nitrogen, phosphates, $\mathrm{BOD}_{5}$ sulphates and suspended solids. The main pollutants in the Rozov Kladenets reservoir are nitrite nitrogen, sulphates and suspended solids (Table 1). 
Table 1. Average annual data on the status of water basins (sites) at the time of the study: Physicochemical analysis - surface water sample.

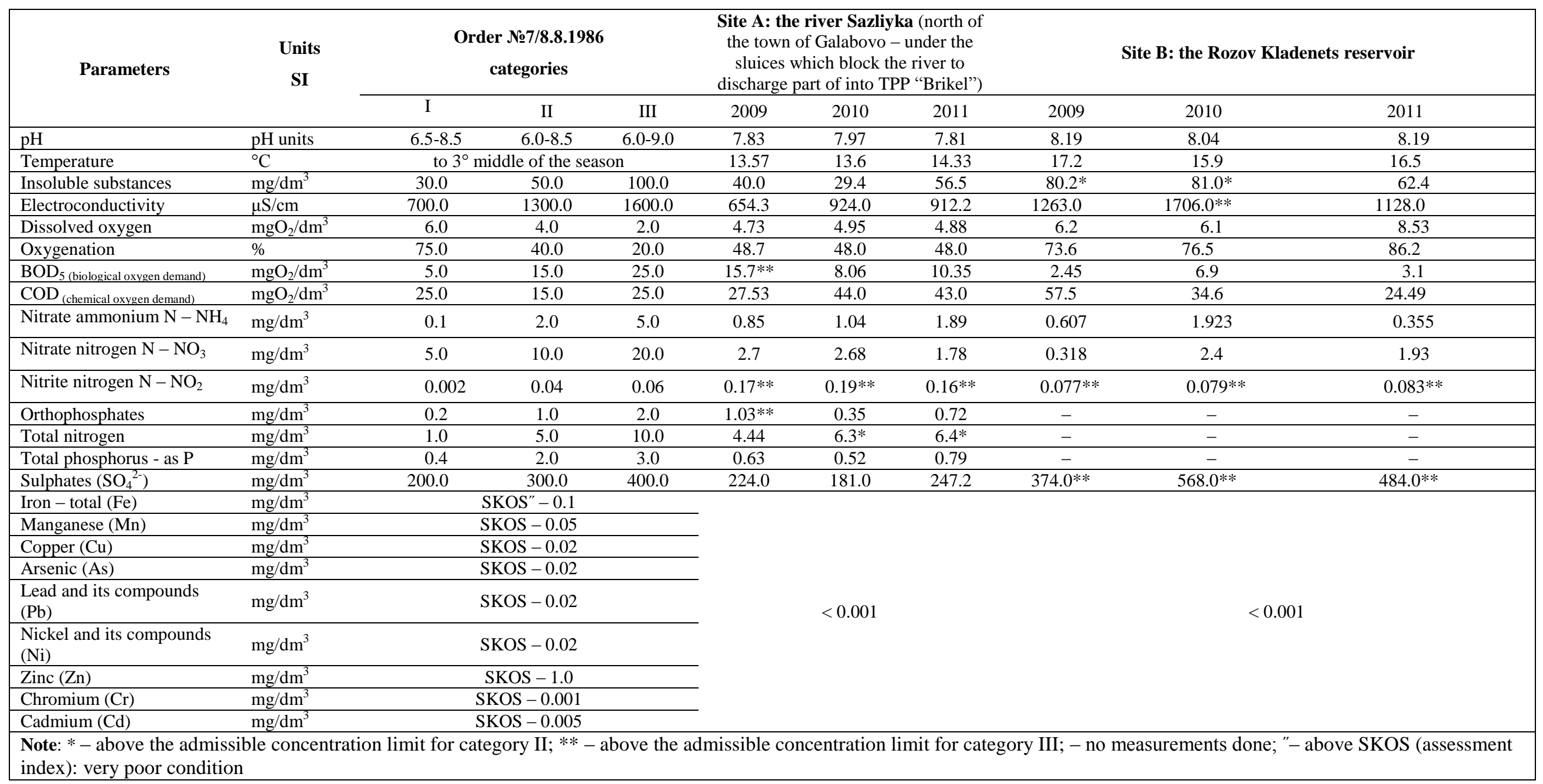


Subject of study and capturing fishes

Subjects of our study were the silver Prussian carp C. gibelio. The ichthyologic material was collected every month, in the time period from April to October 2011. The specimens were determined according to Kottelat and Freyhof (3) and Karapetkova and Zhivkov (10). The fishing was done with fishing nets (cast or throw net) of mesh size 10.0-12.0mm (23-24). The area investigated along the river Sazliyka was 3-4 km long (the catch was done against the stream), while that along the channel of river Sokolitsa and the eastern shore of the Rozov Kladenets reservoir - 1-2 km (24).

\section{Morphological analysis}

The samples fixed in $4 \%$ formalin were studied in the laboratory. The Ethics Board for Experimental Animals, Faculty of Biology at Plovdiv University, approved the animal manipulation and methodology. All experiments were conducted in accordance with the national and international guidelines of the European Parliament and the Council on the protection of animals used for scientific purposes (25).

Specimens were measured (standard length, SL: measured from the anterior-most point of the snout or upper lip to the base of the median caudal rays) to the nearest $1 \mathrm{~mm}$ and weighed (total weight, TW) to the nearest $0.1 \mathrm{~g}(3,23)$. Scales were used for age estimation (26-27). For this purpose, scales were taken from the left side of the fish, above the lateral line, near the dorsal fin (28), and stored in 33\% ethanol (5). The preparations were read under an Olympus SZ51 stereomicroscope. Specimens were grouped into age-classes, on the basis of the number of winters they had lived through before having been caught (27); Roman digits were used to designate the age-classes (I-VI).

Sex of fish was determined by macroscopic and microscopic investigations $(14,23)$. Sex ratio of the specimens was analyzed according to their age.

In ichthyology, the so-called Fulton condition factor (30) is used to assess the overall health of fish populations, on the one hand, and the quality of habitats, on the other. The fish condition in this work was calculated according to Pauly (31), thus: $\mathrm{K}=\left(\mathrm{W} / \mathrm{L}^{3}\right) \times 10^{2}$, where $\mathrm{W}=$ total weight (in grams), $\mathrm{L}=$ standard length (in centimeters).
Statistical analysis

The mathematical processing of the data was performed with standard statistical procedures using the "Statistica for Windows, Release 7.0" software package (32).

The descriptive statistics includes a minimum and maximum value, mean value and an error (mean \pm standard error). Comparisons of mean values (total value) of the traits between individuals of the same age group were conducted with a parametric Student's t-test for independent samples, at a level of significance $\alpha$ $=0.05 ;[\mathrm{p}<0.05]$, because the distribution normalcy of the parameters was checked with the Shapiro-Wilk's test, and a normal distribution was found: $\mathrm{p}>0.05$.

The data for SL and TW were evaluated and the gender factor was excluded, because 556 $(99.64 \%)$ of 558 samples obtained from the river Sazliyka and $997(99.30 \%)$ of 1004 samples from the Rozov Kladenets reservoir were female.

\section{Results and Discussion}

For convenience of comments in the work, each population inhabiting the corresponding site is indicated with its letter: site A (the river Sazliyka) - Population A, and site B (the Rozov Kladenets reservoir) - Population B.

It was found that $99.64 \%$ of Population A consisted of females, and the remaining $0.36 \%$ males. $99.30 \%$ of Population B was female, and $0.70 \%$ - male individuals (Table 2).

It is not an isolated phenomenon that female individuals were dominant in both populations of C. gibelio in Southern Bulgaria (more than $99.00 \%$ ). There are many cases reported in scientific literature about $C$. gibelio populations in which females are dominant and even there is a lack of males. According to Berg (33) most of individuals caught for their study on the Tandovo reservoir in Western Siberia were female, and all specimens were female in the Oxbow reservoir on Labinskaya location of the river Kuban. In Turkey, a dominance of females was also reported $-99.44 \%$ of the composition of $C$. gibelio population in the Buldan reservoir (14). The author explains the reasons for female abundance in the Buldan reservoir with the phenomenon gynogenesis - as the time of spawning of $C$. gibelio in the lake coincides with that of the carp (C. carpio). 
ZHELEV Z., et al.

Table 2. The age-sex distribution of Carassius gibelio populations from the two water basins.

\begin{tabular}{|c|c|c|c|c|c|c|}
\hline \multirow{2}{*}{ Age } & \multicolumn{2}{|c|}{ Female } & \multicolumn{2}{|c|}{ Male } & \multicolumn{2}{|c|}{ Female+Male } \\
\hline & $\mathrm{N}$ & $\% \mathrm{~N}$ & $\mathrm{~N}$ & $\% \mathrm{~N}$ & $\mathrm{~N}$ & $\% \mathrm{~N}$ \\
\hline \multicolumn{7}{|c|}{ The river Sazliyka } \\
\hline I & 62 & 11.11 & - & - & 62 & 11.11 \\
\hline II & 141 & 25.27 & - & - & 141 & 25.27 \\
\hline III & 353 & 63.26 & 2 & 0.36 & 355 & 63.62 \\
\hline Total & 556 & 99.64 & 2 & 0.36 & 558 & 100.00 \\
\hline \multicolumn{7}{|c|}{ The Rozov Kladenets reservoir } \\
\hline I & 43 & 4.28 & - & - & 43 & 4.28 \\
\hline II & 113 & 11.26 & 2 & 0.20 & 115 & 11.45 \\
\hline III & 289 & 28.78 & 2 & 0.20 & 291 & 28.99 \\
\hline IV & 345 & 34.36 & 3 & 0.30 & 348 & 34.66 \\
\hline $\mathrm{V}$ & 126 & 12.55 & - & - & 126 & 12.55 \\
\hline VI & 81 & 8.07 & - & - & 81 & 8.07 \\
\hline Total & 997 & 99.30 & 7 & 0.70 & 1004 & 100.00 \\
\hline $\mathrm{N}-$ numb & imens & & & & & \\
\hline
\end{tabular}

The adaptive role of populations with no males is to ensure the reproduction of a single individual (34). Apart from C. gibelio, there are other populations in natural water bodies consisting entirely or almost entirely of females, such as Heterandria formosa Agassiz, 1853 living in water basins in the USA and Heterandria bimaculata (Heckel, 1848) from North Eastern Mexico, Guatemala and Honduras. The species Poeciliopsis lucida Miller, 1960, P. occidentalis (Baird and Girard, 1853), common in Arizona and Mexico, reproduce only females (35).

It is known that if there is an impaired nutritional base and a deteriorating environment (including the influence of anthropogenic factor, too), the ratio between individuals of both sexes' shifts from the theoretically expected $1: 1$ to a predominance of females (36) in many vertebrate populations, which is reasonable from an evolutionary point of view. The ability of $C$. gibelio to reproduce by gynogenesis, however, does not give grounds the anthropogenic factor to be pointed out as the only reason for the dominance of females in populations inhabiting anthropogenically polluted waters (as in the two water basins near the town of Galabovo). On the other hand, there are some data in the scientific literature about populations of $C$. gibelio living in anthropogenically polluted water basins, where the percentage of male presence is not small (37-38). The authors argue the idea that into anthropogenically transformed water basins, where living conditions have changed and natural selection effects have become stronger, changing of the structure of $C$. gibelio populations gradually occurs - participation of males of their own species in the process of reproduction increases, giving more chances to offspring to survive, at the expense of the vast genetic heterogeneity.

Within the European part of the Russian Federation in the populations of $C$. gibelio, two forms differing in their chromosome set and sex composition, have been found: unisexual and bisexual (34). In various water basins, depending on the environmental conditions, bisexual form includes males and females in different numerical ratios (from $1: 1.5$ to $1: 2$ ). Bisexual individuals of $C$. gibelio are diploid: $2 \mathrm{n}=90-100$ chromosomes (39). Unisexual form includes females that reproduce by gynogenesis and it is triploid: $3 n=135-156$ chromosomes (39). In most water basins in the European part of Russia, both forms live together, forming diploid-triploid complexes dominated by the one or the other form, depending on the geographical location of the water body and the living conditions there. Practically, there are not any visible morphological differences between the two forms of C. gibelio (34). According to Spirina's (38) data, in many anthropogenically polluted water basins in Ulyanovsk region of the Russian Federation, the increasing number of males in $C$. gibelio populations is due to the appearance of bisexual form in them. 
Basing on the findings in the present work, i.e. apparent abundance of females in $C$. gibelio populations in both water basins near the town of Galabovo, it is possible to assume that individuals of unisexual form inhabit them. Both types of form can be found, but the unisexual form is dominant. This assumption needs the support of some cardiovascular research and genetic structure analysis in populations; however, they were not among the objectives of this study.

C. gibelio populations in the river Sazliyka can be divided into three age groups; age groups I-III were represented at the rates of $11.11 \%, 25.27 \%$ and $63.62 \%$, respectively. C.gibelio populations in Rozov Kladenets reservoir formed six age groups; age groups I-VI was represented at the rates of $4.28 \%, 11.45 \%, 28.99 \%, 34.66 \%, 12.55 \%$ and $8.07 \%$, respectively. According to the age frequency distribution, vast majority of Population A consisted of age group III specimens, while in Population B - age groups III and IV specimens; in Population B the number of individuals in age group V was comparatively high as well (Table 2).
ZHELEV Z., et al. In the territory of the former USSR in $C$. gibelio populations, Berg (33) recorded individuals between ages of VI-VIII. In Kazakhstan, for the population of $C$. gibelio that inhabits the reservoirprecipitant Balkyldak, industrial waters from Pavlodar chemical plant containing mercury and heavy metals $(\mathrm{Zn}, \mathrm{Cr}, \mathrm{Fe})$ enter it, most of the individuals were at the age III, IV and V (40). Further south in Turkey, the population of $C$. gibelio in the Buldan reservoir included individuals at the age I-VI (14).

In the present study, length and weight values by age were evaluated, considering all individuals because of gynogenesis observed in the entire group. Mean lengths and weights of each age group from Populations A and B are shown in Table 3 and 4.

Standard length of the samples from Population A ranged between 8.7 and $22.6 \mathrm{~cm}$. About $96 \%$ of the population consisted of the individuals less than 20 $\mathrm{cm}$ in length. The biggest group of fish $(75 \%)$ was found 14 to $20 \mathrm{~cm}$ in length (Table 3, Figure 2).

Table 3. Standard length at age values $(\mathrm{cm})$ of Carassius gibelio from the two water basins.

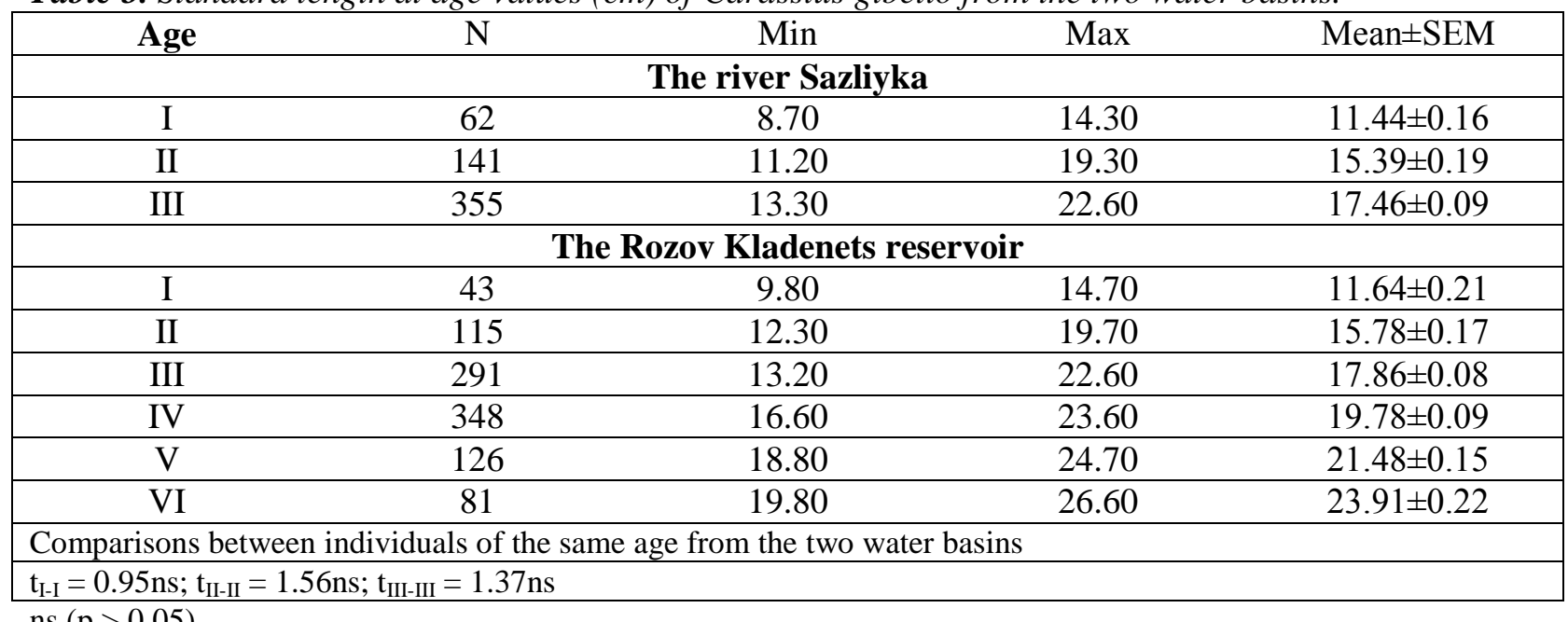

ns (p > 0.05)

Table 4. Total weight at age values ( $g$ ) of C. gibelio from the two water basins.

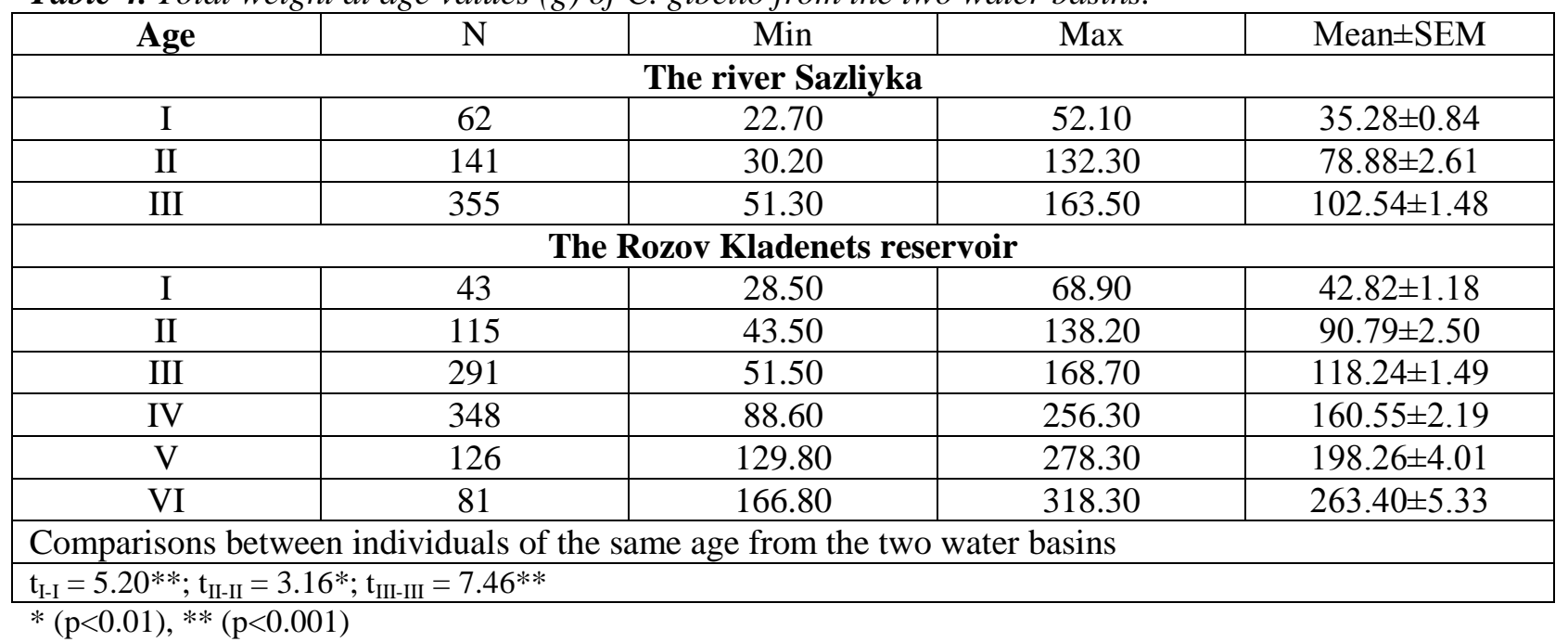




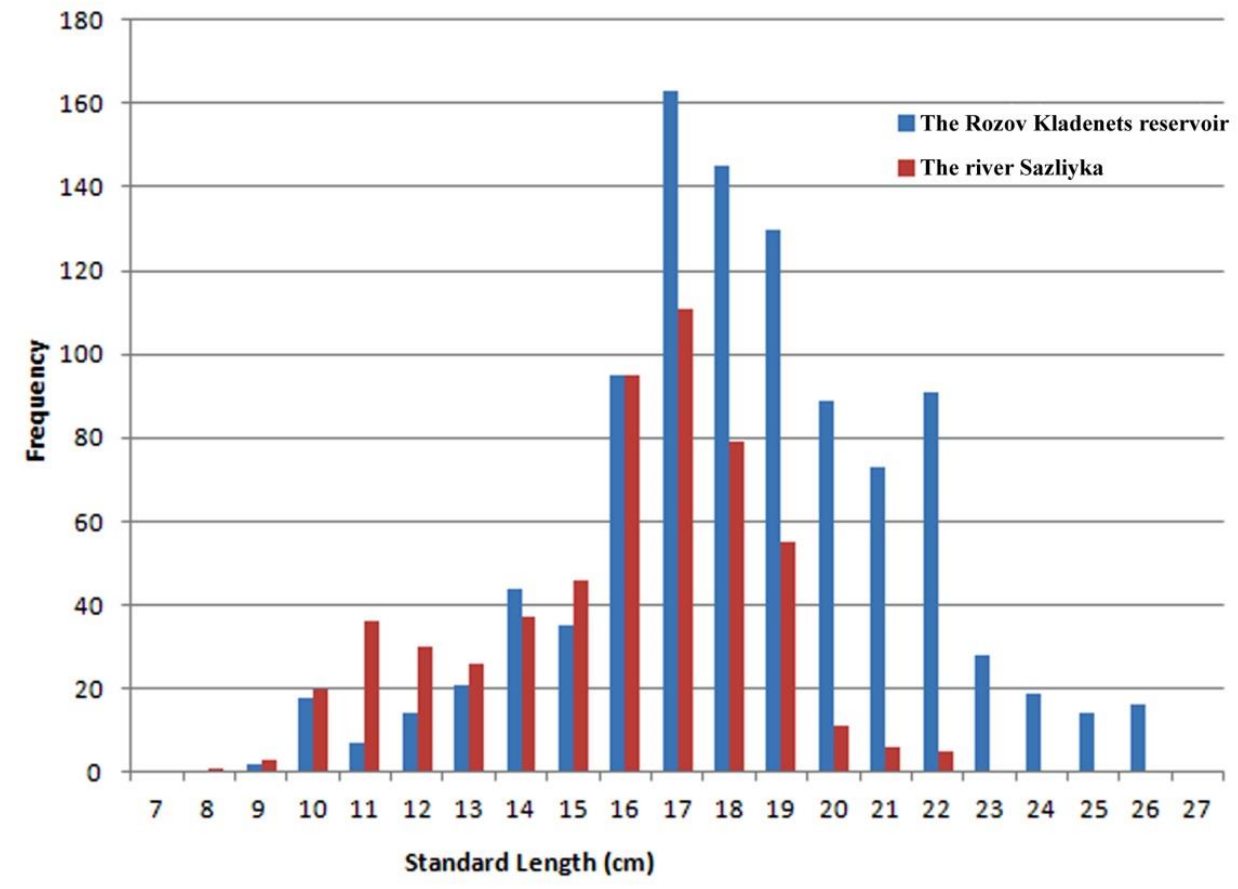

Figure 2. The distribution of standard length $(\mathrm{cm})$.

Individuals less than $150 \mathrm{~g}$ in weight consisted of about $96 \%$ of Population A. The biggest group, in terms of weight, consisted of the specimens of 30 to $140 \mathrm{~g}(88 \%)$. Weight distribution of the specimens ranged between 22.7 and $163.5 \mathrm{~g}$ (Table 4, Figure 3).

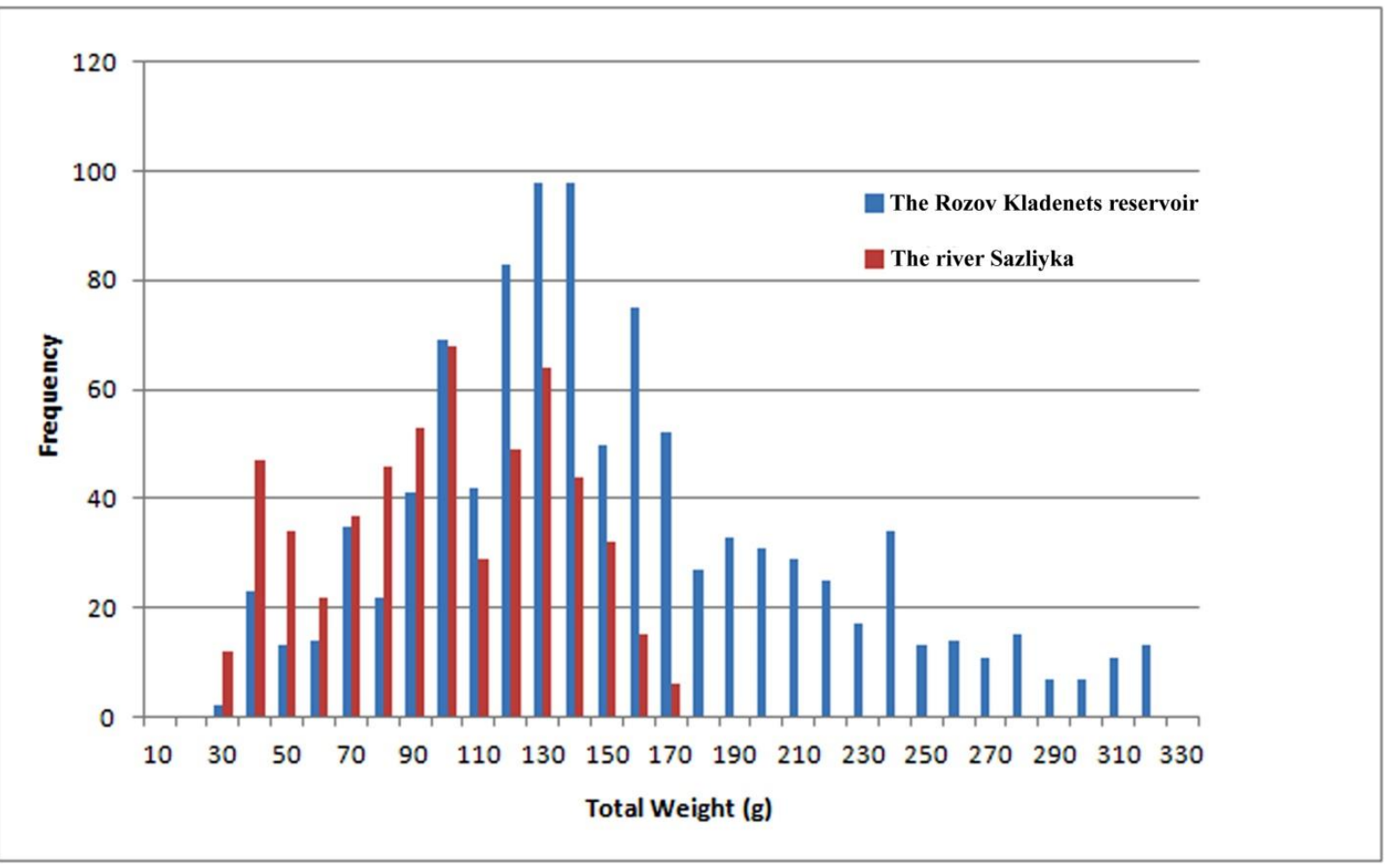

Figure 3. The distribution of total weight (g). 
With regard to the length and weight, the individuals 14 to $20 \mathrm{~cm}$ in length and 30 to $140 \mathrm{~g}$ in weight, which makes them the biggest length and weight group, were found in the age groups of I-III, while most of them were of the age group III.

Standard length of the samples from Population $\mathrm{B}$ ranged between 9.8 and $26.6 \mathrm{~cm}$. About $95 \%$ of Population B consisted of the individual less than $24 \mathrm{~cm}$ in length. The biggest group of fish (86\%) was that of 14 to $23 \mathrm{~cm}$ in length (Table

\section{3, Figure 2).}

Individuals less than $240 \mathrm{~g}$ in weight consisted of about $90 \%$ of Population B. The biggest group, in terms of weight, consisted of specimens of 60 to $240 \mathrm{~g}(85 \%)$. Weight distribution of the specimens ranged between 28.5 and $318.3 \mathrm{~g}$ (Table 4, Figure 3).
With regard to the length and weight, the individuals 14 to $23 \mathrm{~cm}$ in length and 60 to $240 \mathrm{~g}$ in weight, which makes them the biggest length and weight group, were found in the age groups I-VI, while most of them were of the age group IV.

Statistically significant differences between individuals of the relevant age groups of Populations A and B, in terms of standard length, were not found (Table 3). At the same time, individuals of age groups I, II and III of Population B had a statistically significant higher weight than those of the respective age groups in Population A (Table 4).

Condition factor, expressing the feeding activity during the year, was calculated separately for males and females, although the males were scarce in both populations (Table 5).

Table 5. Average condition factor values for different ages of Carassius gibelio females and males from the two water basins.

\begin{tabular}{|c|c|c|c|c|}
\hline Age & $\mathrm{N}$ & Min & Max & Mean \pm SEM \\
\hline \multicolumn{5}{|c|}{ The river Sazliyka } \\
\hline \multicolumn{5}{|c|}{ Female } \\
\hline I & 62 & 1.260 & 4.186 & $2.317 \pm 0.069$ \\
\hline II & 141 & 1.354 & 3.489 & $2.151 \pm 0.033$ \\
\hline III & 353 & 1.328 & 2.796 & $1.991 \pm 0.011$ \\
\hline \multicolumn{5}{|c|}{ Male } \\
\hline III & 2 & 1.751 & 2.265 & $2.008 \pm 0.025$ \\
\hline \multicolumn{5}{|c|}{ The Rozov Kladenets reservoir } \\
\hline \multicolumn{5}{|c|}{$\begin{array}{c}\text { Female } \\
\end{array}$} \\
\hline I & 43 & 1.744 & 4.493 & $2.683 \pm 0.098$ \\
\hline II & 113 & 1.681 & 3.374 & $2.272 \pm 0.027$ \\
\hline III & 289 & 1.416 & 2.799 & $2.107 \pm 0.013$ \\
\hline IV & 345 & 1.703 & 2.383 & $2.024 \pm 0.006$ \\
\hline $\mathrm{V}$ & 126 & 1.801 & 2.281 & $2.004 \pm 0.009$ \\
\hline VI & 81 & 1.619 & 2.294 & $1.919 \pm 0.019$ \\
\hline \multicolumn{5}{|c|}{ Male } \\
\hline II & 2 & 2.289 & 2.458 & $2.373 \pm 0.071$ \\
\hline III & 2 & 1.968 & 2.011 & $1.989 \pm 0.024$ \\
\hline IV & 3 & 1.912 & 2.119 & $2.008 \pm 0.092$ \\
\hline \multicolumn{5}{|c|}{ Comparisons between individuals of the same age from the two water basins } \\
\hline $\mathrm{t}_{\mathrm{FI}-\mathrm{I}}=3.07 * ;$ & 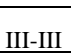 & $I=0.56$ & & \\
\hline
\end{tabular}

Females of age groups I, II and III of Population A had statistically significantly lower CF values than females of the relevant age groups of Population B. In the only comparison made between males from the two populations - those in age group III - a statistically significant difference was not found, but here, the small number of individuals should be considered as well (Table 5).
According to the age, the condition factor in females decreased inversely proportional to age. Such a trend was also found for the condition factor in males, despite the small size of the sample. Similar reductions in the values of the condition factor of females from senior age groups (not in males) were also recorded for $C$. gibelio populations in the Buldan reservoir in Turkey (14). An opposite trend - increasing of 
$\mathrm{CF}$ values at the transition of senior age groups was reported for $C$. gibelio population from the reservoir-precipitant Balkyldak in Kazakhstan (40).

\section{CONCLUSIONS}

According to the results obtained in this study, the following conclusions can be drawn:

1) Deteriorated living conditions in the river Sazliyka and the Rozov Kladenets reservoir, near the town of Galabovo, have caused disorders in the structure of $C$. gibelio population from the two water basins, and they are the following:

a) Both populations consist almost entirely of females.

b) Individuals of age group III (and IV in the Rozov Kladenets reservoir) are dominant in both populations.

2) The developmental stability of $C$. gibelio population that inhabits the river Sazliyka below the town of Galabovo is impaired at a greater extent than that in the Rozov Kladenets reservoir. The reasons for such claim are:

a) Within the area of the study, there are no individuals from the senior age groups in the river (I-III), while the age range is wider (I-VI) in the Rozov Kladenets reservoir.

b) Most of the population in the river Sazliyka consists of sexually mature individuals that have body length SL: 14-20 cm and body weight TW: 30-140 g., whilst in the Rozov Kladenets reservoir most has body length SL: $14-23 \mathrm{~cm}$ and body weight TW: 60-240 g.

c) $\mathrm{CF}$ values of female individuals from all age groups within the population of $C$. gibelio in the river Sazliyka are statistically significantly lower than those of the females of the respective age groups within the population of Rozov Kladenets reservoir.

\section{REFERENCES}

1. Holopainen, I.J., Tonn, W.M. and Paszkowski, C.A., Tales of two fish: the dichotomous biology of crucian carp (Carassius carassius (L.)) in Northern Europe. Ann. Zool. Fennici, 34: 1-22, 1997.

2. Szczerbowski, J.A., Carassius auratus. The Freshwater fishes of Europe. In: Bãnãrescu, P.M. and Paepke, H.J. (eds.), Cyprinidae and Gasterosteidae. AULA-Verlag $\mathrm{GmbH}$, Wiebelsheim, pp. 5-41, 2001.

3. Kottelat, M. and Freyhof, J., Handbook of European Freshwater Fishes, Kottelat, Cornol and Freyhof, Berlin, Deutschland, 2007.

4. Vekhov, D.A., The population of the goldfish Carassius auratus (Cypriniformes, Cyprinidae) with "golden individuals" in the
ZHELEV Z., et al.

pond of the Volgograd. Ichthyology, 48 (3): 374-383, 2008. (In Russian).

5. Lorenzoni, M., Ghetti, L., Pedicillo, G. and Carosi, A., Analysis of the biological features of the goldfish Carassius auratus auratus in Like Trasimeno (Umbria, Italy) with a view to drawing up plans for population control. Folia Zool., 59 (2): 142-156, 2010.

6. Kottelat, M., European freshwater fishes. An heuristic checklist of the freshwater fishes of Europe (exclusive of former USSR), with an introduction for non-systematists and comments on nomenclature and conservation. Biologia (Bratislava), 52 (Suppl. 5): 1-271, 1997.

7. Gerstmeir, R. and Roming, T., Zoetwater vissen van Europa, Franck-Kosmos Verlags, Stuttgart, Deutschland, 1998.

8. Wheeler, A.C., Status of the crucian carp Carassius carassius (L.) in the UK. Fisheries Management and Ecology, 7: 315-322, 2000.

9. Papoušek, I., Vetešník, L., Halačka, K., Lusková, V., Humpl, M. and Mendel, J., Identifi cation of natural hybrids of gibel carp Carassius auratus gibelio (Bloch) and crucian carp Carassius carassius (L.) from lower Dyje River floodplain (Czech Republic). J. Fish Biol., 72: 1230-1235, 2008.

10.Karapetkova, M. and Zhivkov, M., Fish in Bulgaria, Gea-Libris Publishing House, Sofia, Bulgaria, 2010. (In Bulgarian).

11.Crivelli, A.J., Are fish introductions a threat to endemic freshwater fishes in the northern Mediterranean region? Biological Conservation, 72: 311-319, 1995.

12.Halačka, K., Lusková, V. and Lusk, S., Carassius gibelio in fish communities of the Czech Republic. Ecohydrology and Hydrobiology, 3: 133-138, 2003.

13.Lorenzoni, M., Ghetti, L. and Mearelli, M., Native and exotic fi sh species in the Tiber River watershed (Umbria - Italy) and their relationship to the longitudinal gradient. Bull. Fr. Piscic. Ichthyol., 382: 19-44, 2006.

14.Sarı, H.M., Süleyman, B., Ustaoğlu M.R. and İlhan, A., Population Structure, Growth and Mortality of Carassius gibelio (Bloch, 1782) in Buldan Dam Lake. Turk. J. Fish. Aquat. Sc.(TrJFAS), 8: 25-29, 2008.

15.Buth, D.G., Dowling, T.E. and Gold, J.R., Molecular and Cytological Investigation. In: Winfield, I.J. and Nelson, J.S. (eds.), Cyprinid Fishes: Systematic, Biology and Exploitation. Chapman and Hall, London, Great Britain, pp. 83-126, 1991. 
16.Yankova, N.V., Niyazov, N.S. and Muhachev, I.S., Rational use of stocks of carp from ponds in the Tyumen region. Fisheries, 5: 53-55, 2006. (In Russian).

17. Yankova, N.V., Muhachev, I.S. and Aleshina, O.A., Prussian carp as an indicator of the state of the lake ecosystem under anthropogenic impact. Problems of environmental management in areas with complex ecological situation. In: Proceedings of the SecondAll-Russian Scientific Conference-Tyumen, Tyumen State University Publisher, Tyumen, pp. 113-115, 2003. (In Russian).

18. Regional Development Strategy of the Stara Zagora Region (2014-2020), National Centre for Area Development. http://www. sz.government.bg (In Bulgarian), 2014

19.Council Directive 91/271/EEC (1991) of 21 May 1991 concerning urban waste-water treatment, Special edition in Bulgarian: Chapter 15 vol. 002/EEC. Official Journal of the European Union, L 135, 30.05.1991.

20.Council Directive 92/43/EEC of 21 May, 1992 on the conservation of natural habitats and of wild fauna and flora. Official Journal of the European Union, L 206, 22.7.1992.

21. Newsletters on the state of water in the river Sazliyka and Rozov Kladenets" reservoir, 2009-2011. Ministry of Environment and Water of Bulgaria. Basin Directorate for Water Management. Eastern Aegean region of Plovdiv. http://www.bg-ibr.org. (In Bulgarian).

22.Regulation № 7of 08.08. 1986 for indicators and standards for determining the quality of flowing surface water in the Republic of Bulgaria. Promulgated, State Gazette, № 96. 12.12.1986 (Annulled 05.03.2013).

23.Pravdin, I.F., Study guide of fishes (mainly freshwater). The food-processing industry. Science, Moscow, Russia, 1966 (In Russian).

24.Sutherland, W.J., The Conservation Handbook: Research, Management and Policy,Blackwell, Oxford, Great Britain, 2000

25.Directive 2010/63/EU of the European Parliament and of the Council of 22 September 2010 on the protection of animals used for scientific purposes. Official Journal of the European Union, L 276/33, 20.10.2010.

26.Kafanova, V.V., Methods for determining the age and growth of fish, Tomsk State University Publisher, Tomsк, Russia, 1984. (In Russsian).
ZHELEV Z., et al.

27.Anderson, R.O. and Neumann, R.M., Length, weight and associated structural indices. In: Murphy, B. R. and Willis, D.W. (eds.), Fisheries techniques. American Fisheries Society. Bethesda, New Work, USA, pp. 447482, 1996.

28.Howland, K.L., Gendron, M., Tonn, W.M. and Tallman, R.F., Age determination of a long-lived coregonid from the Canadian north: comparison of otoliths, fin rays and scales in inconnu (Stenodus leucichthys). Annls. Zool. Fennici., 41: 205-214, 2004.

29.De Vries, D. R. and Frie, R.V., Determination of age and growth. In: Murphy, B.R. and Willis, D.W. (eds.), Fisheries Techniques. American Fisheries Society. Bethesda, New Work, USA, pp. 483-512, 1996.

30.Fulton, T.W. The rate of growth of fishes. 20th Annual Report of the Fishery Board of Scotland, 3: 326-446, 1902.

31.Pauly, D., Some simple methods for the assessment of tropical fish stocks. FAO Fisheries Technical Paper, Rome, Italy, 1983.

32. Statistica for Windows, version 7.0. Statsoft Inc., Tulsa USA, 2004.

33.Berg, L.S., Freshwater of the USSR and Adjacent Countries. Israel Program for Scientific Translation V. 2 (4 ${ }^{\text {th }}$ Edition), Jerusalem, Israel, 1964.

34.Golovinskaya, K.A., Romashov, D.D. and Cherfas, N.B., Unisexual and bisexual forms of goldfish (Carassius auratus Bloch). Ichthyology, 4: 614-629, 1965. (In Russian).

35.Nikolsky, G.V., The ecology of fishes, High School Publishing, Moscow, Russia, 1963 (In Russian).

36.Kalmus, H. and Smith, A., Evolutionary origin sexual differentiation and sex ratio. Nature, 186 (4730): 1004-1006, 1960.

37.Goncharenko, N.I., Peculiarities of the Sexual Structure of Crucian Populations in Lower Danube. Vestnik zoologii, 35 (2): 89-92, 2001. (In Russian).

38.Spirina, E.V., Particular, the sexual population structure goldfish ponds Ulyanovsk region. Bulletin of Altai State Agrarian University, 2 (76): 66-70, 2011. (In Russian).

39.Vasiliev, V.P., Evolutionary karyology fish, Science, Moscow, Russia, 1985. (In Russian).

40.Ilyushchenko, M. A., Uskov, G.A. Zyryanova, N.A., Galushchak, S.S. and Skakun, V. A., Contamination of mercury $(\mathrm{Hg})$ fish fauna technical reservoir Balkyldak. Bulletin of Kazan University, 2 (11): 1-4, 2002. (In Russian). 
ZHELEV Z., et al. 